\title{
Adaptation and Mitigation for meeting the Climate Change through Urban Plans: Assessing Urban Development Plans of Tehran, Iran
}

Farhad Feizi *

Department of Architecture and Urban Planning, University of Art, Tehran, Iran.
* Correspondence: Fafeizi92@gmail.com

\begin{abstract}
Climate change has emerged as one of the defining issues of the early 21st century. It is now more certain than ever and poses a serious threat to sustainable urban development. Climate change has many destructive effects on cities. Land subsidence, rising air pollutants, severe storms, dust and water scarcity are just some effects of this phenomenon in the urban area of Tehran. Urban management must be prepared to deal with these effects and adopt policies to mitigate and adapt to climate change. One of these tools in urban planning is urban development plans. The plans can have a great impact on controlling and counteracting with the effects of climate change. In this research, using content analysis method, 6 dimensions and 31 indicators have been used to evaluate 8 city and region development plans of Tehran from the view of reflecting the effects of climate change. Indicators were scored after studying the content of the plans. Findings indicate that among the reviewed plans, the second and third five-year development plans of Tehran with $61.9 \%$ and $61.3 \%$ as the highest rate and plan to reduce air pollution in Tehran and the transportation master plan with $20.6 \%$ and $23.2 \%$, respectively have the least attention to the effects of climate change. Also, among the indicators, the urban transportation sector with $54.3 \%$ as the highest and the energy sector with $20.5 \%$ have the least attention to mitigation and adaptation policies.
\end{abstract}

Keywords: Urban Development Plans; Climate Change; Adaptation and Mitigation Policies; Tehran Metropolis.

\section{Introduction}

Climate change is one of the most important issues that inevitably involves cities and has been introduced as the most important challenge of the 21st century which its devastating effects can weaken the ability of all countries to achieve sustainable development. Climate change and variability is not only considered as an important environmental issue but also as an important issue in politics, economics and law at the international level [1]. Climate change in the present era is the most important threat to sustainable development that damages natural resources, basic resources, environment, human health, food security, economic activities and so on. In recent decades, the effects of urbanization and climate change are converging on dangerous paths that pose serious threats to the world's sustainability in environmental, economic and social dimensions [2]. Due to the lifestyle and urban economy, cities are accounted for more than $70 \%$ of greenhouse gas emissions which are the main drivers of climate change. Today, climate change is no longer a farfetched possibility, but a current reality, as the damage caused by floods and hurricanes has been repeated over the years, especially in cities with high population and capital. Cities are part of the problem of climate change and also a key part of the solution to climate change [3]. More than 50 percent of the world's population now lives in urban areas, and this number is expected to reach 66 percent by 2050 [4].

Addressing climate change requires different levels of coordination not only between countries but also between different levels of the public and private sectors. Cities are 
considered as an important place in response to the effects of climate change [5]. Although climate change is a profound global issue, it is also a local issue because urban areas play a crucial role in climate change [6]. Urban planning is important in climate change management because proper urban planning creates a better foundation for sustainable development than unplanned cities [7]. Therefore, it is necessary for cities to deal with it by adopting adaptation and mitigation policies in order to limit the scope of the climate change effects. Adaptation and mitigation functions both require urban planning. Urban planning and development control can reduce the impact of urban heat islands by creating open spaces and parks as heat outlets in urban areas, reducing the ecological footprint by planning for greater productivity (energy), compaction of urban forms and mixed land uses and transition to public transport [8]. In addition, land use planning as the heart of urban planning can also play an important role in solving the problem of climate change.

Tehran is the capital of the Iran, with a population of around 9 million in the city and 16 million in the wider metropolitan area and is considered as one of the largest cities in the country which always faces many challenges including climate change. So far, due to the limitations and shortcomings of studies and statistics on the effects of climate change in Tehran, incidents and events caused by climate change in this city have not been clearly recorded, but this city as one of the world's metropolises has always faced with many environmental problems that is likely to reflect the consequences of climate change in the near future. Tehran is also facing with the other devastating effects of climate change such as land subsidence, rising air pollutants, severe storms, dust and water scarcity which have become major challenges for this metropolis.

In general, urban centers need to be prepared with the right tools to deal with the effects of climate change. Urban development plans as one of the main tools of urban planning have a great role in guiding and controlling climate change. In this study, the urban development plans of Tehran have been studied and evaluated. The aim of this study is to show whether climate change considerations are taken into account in these plans and to what extent the policies of these plans are in line with global climate change.

\section{Literature Review}

Due to the wide and complex dimensions and contexts in urban issues especially climate change, the history of research is very diverse and extensive and some of the most important are discussed below. Diana Reckien et al. (2018) in a study entitled "How are cities planning to respond to climate change? Assessment of local climate plans from 885 cities in the EU-28", have studied the state of local planning for climate change by collecting and analyzing information about local climate mitigation and adaptation plans across 885 urban areas of the EU-28. This study provides a framework for analysis that categorizes local climate plans in terms of their alignment with spatial policies (local, national and international) and other climate-related policies. From the eight types of local plans identified, three types of independent local climate plans are categorized in the form of A1 (autonomously produced plans), A2 (Plans produced to comply with national regulations) or A3 (plans developed for international climate networks). Approximately $66 \%$ of EU cities have a type A1, A2 or A3 mitigation plans, $26 \%$ have adaptation plans and $17 \%$ have a joint adaptation and mitigation plans. While about $33 \%$ lack any form of standalone local climate plan (i.e. what are classified as A1, A2, A3 plans). There are more mitigation plans than adaptation plans [9].

Stevens et al. (2017) study plans of 2011 in British Columbia, Canada, and review updated versions of those plans for 2015. An area was studied in which the climate change was less addressed in the plans. The analysis of this article shows which cities keeping pace with the implementation of their plans and policies in order to respond to the new climate conditions. Research findings show that the content of climate change in plans has not changed much from 2011 to 2015, and there is still much room for improvement [10].

In another study, $\mathrm{Hu}$ (2017) in "Evaluating climate change mitigation and adaptation policies on the U.S. 50 States hazard mitigation plans" presents 18 indicators to measure climate change considerations in 50 hazard mitigation plans. Samples of this study include 
hazard mitigation plans in all 50 US states. Most of them belong to the years 2013 and 2014. 18 indicators were used for evaluation and were divided into three categories (awareness, evaluation and action). Findings indicate that the concepts related to climate change and historical events were well identified by most hazard mitigation plans [11].

Viegas et al. (2013) in an article entitled "Urban land planning: The role of a Master Plan in influencing local temperatures", discusses the role and impact of a master plan in understanding and controlling urban temperature rise over several decades. They propose a framework including land use classification and its dimensions are compared with the master plan of Porto Alegre as a case study. The results are shown in two sub-categories: A discussion about the problems of developing urban climate change model and a framework for assessing climate change in land use planning. Then the Porto Alegre master plan is discussed and the main features of the city master plan are compared with the proposed land use planning framework. Master plans usually do not include climate aspects, especially in developing countries. This paper proposes a framework with ten categories to assess climate change in urban land use planning. Each category includes features that involve a set of relationships affecting local temperature changes. These analyzes have also been performed for the Porto Alegre master plan in southern Brazil. The findings of this study show that the Porto Alegre Master Plan is largely in line with climate change. However, the plan does not include local climate control and greenhouse gas emissions and is inefficient to improve energy efficiency [12].

Damian Pitt (2010) examines 255 US cities in an article entitled "The impact of internal and external characteristics of climate mitigation policies by US municipalities" The results of the study were combined with secondary data and multivariate regression technique was used to estimate the impact of 15 demographic, political, managerial, economic and environmental variables on the acceptance of plans and policies to reduce the effects of climate change. This article shows the factors that lead to the connection of cities to political networks. It also proposes policies to reduce greenhouse gas emissions but is not very efficient in overcoming these barriers. The purpose of this article is to increase the understanding of climate change mitigation planning by examining the relationship between plans and policies with demographic, economic, environmental and political management factors. The impact of neighborhoods, the presence of staff in the field of energy and climate planning and the level of environmental activities of communities, have the greatest impact on the adoption of climate mitigation policy. Findings indicate that climate mitigation planning derived from internal processes and cities that are successful in this area, are not suitable for any of the indicators based on their demographic, economic and environmental characteristics [13].

In general, most books and articles on climate change have dealt with this phenomenon from an environmental point of view and its effects on water resources, agriculture and natural resources, and the effects of climate change on cities and urban plans has received less attention.

\section{Conceptual Background}

\subsection{Climate change}

Climate change means any specific change in patterns expected for the average climate condition that may occur in the long time in a particular region or for the global climate as a whole. Climate change reflects abnormal changes in the climate within the Earth's atmosphere and its consequences in different parts of the globe [14].

The latest report of the Intergovernmental Panel on Climate Change (IPCC) is the fifth report, known as the Paris Agreement. The Paris Agreement is a contract under the United Nations Framework Convention on Climate Change, which aims to address issues related to adjustment, funding and adaptation with the GHG crisis by 2020. The purpose of the Convention is to promote the implementation of the United Nations Framework Convention on Climate Change by maintaining an increase in global average temperatures below $2^{\circ} \mathrm{C}$ to mitigate the risks and effects of climate change, increase the ability to 
adapt to the effects of climate change, create conditions to reduce greenhouse gas emissions in a way that does not impair the food production process and to adapt the economic flow to a mechanism to reduce greenhouse gas emissions. This agreement is considered as the motivation and driving force for the elimination of investment in the field of fossil fuels and the first comprehensive climate pact in the world. According to the Paris Agreement, Iran has volunteered to reduce its greenhouse gas emissions by $4 \%$ until 2030 and increase this number to $12 \%$ if sanctions are lifted [15].

According to the World Economic Forum in 2019, Iran is the seventh largest emitter of greenhouse gases in the world (Table 1). According to the National Climate Change Report (Second Report), about $80 \%$ of the causes of climate change and increase in greenhouse gases in the country are related to the consumption of fossil energy, about $10 \%$ are related to polluting industries and the rest are related to deforestation [16]. Iran is one of the most impressive countries on climate change due to its hydrocarbon resources and location in the Earth's desert belt.

Table 1. Main countries responsible for global CO2 emissions, modified from [17]

\begin{tabular}{llll}
\hline Rank & Country & Emissions in 2017 (MtCO2) & \% of Global Emissions \\
\hline$\# 1$ & C China & 9,839 & $27.2 \%$ \\
\hline$\# 2$ & United States & 5,269 & $14.6 \%$ \\
\hline$\# 3$ & India & 2,467 & $6.8 \%$ \\
\hline$\# 4$ & - Russia & 1,693 & $4.7 \%$ \\
\hline$\# 5$ & - Japan & 1,205 & $3.3 \%$ \\
\hline$\# 6$ & - Germany & 799 & $2.2 \%$ \\
\hline$\# 7$ & I Iran & 672 & $1.9 \%$ \\
\hline$\# 8$ & D Saudi Arabia & 635 & $1.8 \%$ \\
\hline$\# 9$ & :: South Korea & 616 & $1.7 \%$ \\
\hline$\# 10$ & I+ Canada & 573 & $1.6 \%$ \\
\hline
\end{tabular}

\subsection{The effects of climate change on different sectors}

Urban areas are exposed to the greatest and most severe consequences of climate change. The consequences of climate change within cities do not affect all groups in the same way, but vary by gender, age, race, and wealth. Most of the urban centers in developing countries are growing rapidly and it is more prevalent in the informal sectors. Thus, these urban centers have minimum equipment for meeting the threats of climate change. Climate change can affect water resources, services, ecosystems, energy distribution, industry and services in surrounding cities. It can disrupt local economic systems and people's livelihoods and in some cases lead to widespread migration. Such effects extend to regions, cities, economic sectors or socioeconomic groups. Instead, the consequences of climate change exacerbate existing inequalities; As a result, climate change can disrupt social dynamics and exacerbate poverty [18]. The categorized consequences of climate change in cities are shown in Table 2.

Table 2. Consequences of climate change in terms of different dimensions and sectors in cities [18]

\begin{tabular}{lll}
\hline Dimensions & Indicators & Description \\
\hline $\begin{array}{l}\text { Physical-In- } \\
\text { frastructure } \\
\text { impacts }\end{array}$ & $\begin{array}{l}\text { Residential and } \\
\text { commercial struc- } \\
\text { tures }\end{array}$ & $\begin{array}{l}\text { Flooding, Coastal erosion and saltwater intrusion and land Subsidence resulting in sig- } \\
\text { nificant damage to pipelines, building foundations and other infrastructure. }\end{array}$ \\
\cline { 2 - 3 } & $\begin{array}{l}\text { Transportation sys- } \\
\text { tems }\end{array}$ & $\begin{array}{l}\text { Disrupt transportation systems, damage to transportation infrastructure, such as high- } \\
\text { ways, seaports and bridges. }\end{array}$ \\
\cline { 2 - 3 } & Energy systems & $\begin{array}{l}\text { Effect on both energy demand and supply. Increased energy demand as a result of urban } \\
\text { population growth, changes in local temperature conditions and the effects of the urban } \\
\text { heat island, reduced hydropower generation capacity caused by drought }\end{array}$ \\
& $\begin{array}{l}\text { Decreased rainfall and increased temperature affect the availability, refinery and distri- } \\
\text { bution of water. Decreased water reserves as a result of changing rainfall patterns, de- } \\
\text { clining river flows and groundwater aquifers, increasing water demand in cities due to }\end{array}$ \\
\hline
\end{tabular}


rising temperatures, the occurrence of heat waves and population growth, increasing water pollution and diseases

\begin{tabular}{lll}
\hline $\begin{array}{l}\text { Economic im- } \\
\text { pacts }\end{array}$ & $\begin{array}{l}\text { Sectoral economic } \\
\text { impacts }\end{array}$ & $\begin{array}{l}\text { Negative impact on the prosperity of commercial activities, tourist attraction, insurance } \\
\text { and banking, energy supply and demand, industrial and mining activities }\end{array}$ \\
\cline { 2 - 3 } Ecosystem services & $\begin{array}{l}\text { The destruction of ecosystem services (oxygen production, carbon absorption, pollution } \\
\text { refinery, etc.) disturbs the environmental balance, providing food and human health in } \\
\text { cities. }\end{array}$ \\
\cline { 2 - 3 } & Livelihood impacts & $\begin{array}{l}\text { Climatic hazards destroy people's livelihoods. These assets include natural capital, so- } \\
\text { cial relations (political and social capital), skills (human capital), infrastructure (physical } \\
\text { capital), and financial resources and capital. }\end{array}$ \\
\hline Social impacts & $\begin{array}{l}\text { The vulnerability of low-income groups is due to living in dangerous places and lacking } \\
\text { adequate infrastructure and desirable buildings. Also, these groups do not have enough } \\
\text { information and capacity to act against climate risks. }\end{array}$ \\
\cline { 2 - 3 } & $\begin{array}{l}\text { Women are less able to overcome the consequences of climate change due to lack of } \\
\text { financial resources to invest in housing and resilient areas. Urban planning often ignores } \\
\text { the needs of women. }\end{array}$ \\
\cline { 2 - 3 } & $\begin{array}{l}\text { Most children and the elderly are vulnerable to the consequences of climate change } \\
\text { Age }\end{array}$ & $\begin{array}{l}\text { Discriminatory structures often lead to the segregation of minorities in the vicinity of } \\
\text { high-risk areas, which increases their vulnerability to the consequences of climate } \\
\text { change. }\end{array}$ \\
\hline $\begin{array}{l}\text { Ethnic and other } \\
\text { minorities }\end{array}$ & \\
\hline
\end{tabular}

\subsection{Strategies for meeting the effects of climate change}

Generally, there are two approaches of mitigation and adaptation in the field of dealing with the destructive effects of climate change which are discussed below.

\subsubsection{Mitigate greenhouse gas emissions in metropolitan areas}

The mitigation approach means helping to reduce the magnitude or severity of climate change by reducing greenhouse gas emissions from human activities [18]. Climate change mitigation strategy relies on reducing greenhouse gas emissions to reduce global warming. Given the need to rapidly reducing greenhouse gas emissions, a set of measures in all areas of urban performance should be considered. Many cities use mitigation strategies and set their own policies to achieve it at a given time [19]. The mitigation strategy aims to reduce carbon emissions by $48 \%$ until 2025 with adopting a new policy to achieve carbon-free transportation by 2050. An analysis of 200 European cities shows that communities that have already adopted a mitigation strategy, have been able to reduce only $27 \%$ of total emissions [20].

\subsubsection{Adaptation to the consequences of climate change in metropolitan areas}

As defined by the Intergovernmental Panel on Climate Change, adaptation to climate change includes all measures to reduce the vulnerability of a system (e.g. city), population groups (e.g. vulnerable population in the city) or individuals and households against adverse consequences of climate change. Adaptation to climate variables includes measures to reduce a system's vulnerability to short-term climate shocks (which may or not be affected by climate change) [18]. Their goal is to reduce the effects of climate change and improve adaptation capacity. Effective implementation of adaptation measures can reduce regional vulnerabilities and at the same time create potential growth opportunities. The interest in adaptation compared to the mitigation has recently developed, and as a result, adaptation research is still in its infancy and often inadequate, especially in developing countries [1].

While the mitigation addresses the climate change decline, adaptation is concerned with undermining the adverse effects of climate change. Although they have a common ultimate goal of sustainable development in human society, but in practice they have also many differences, including the scale of performance (Figure 1). The integration of mitigation and adaptation approaches is shown in Table 3, which includes the policies through which the evaluation of Tehran's development plans has been carried out. 


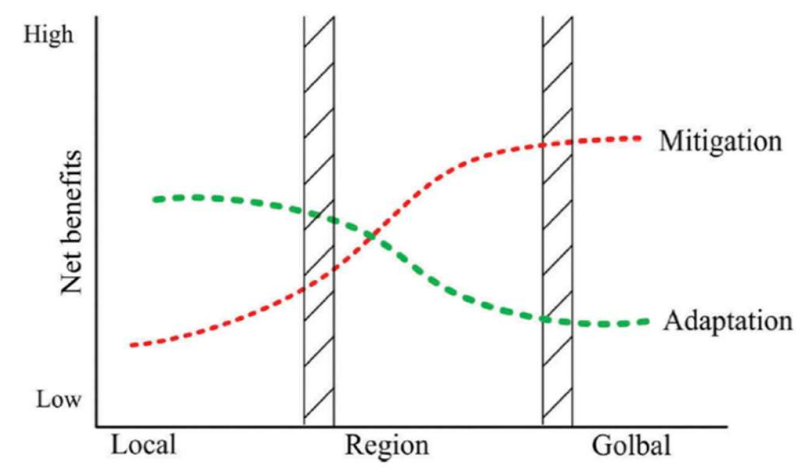

Figure 1. Comparisons of net benefits of mitigation and adaptation in different scales [21]

Table 3. Framework for evaluating urban development plans from the perspective of climate change effects [5-18-22, 23]

\begin{tabular}{|c|c|c|c|}
\hline Approach & Dimensions & Mitigation and adaptation policies & \\
\hline \multirow[t]{3}{*}{ Mitigation } & $\begin{array}{l}\text { Urban De- } \\
\text { velopment }\end{array}$ & $\begin{array}{l}\text { - Land use planning and urban design to limit } \\
\text { energy consumption; } \\
\text { - Reuse abandoned lands to encourage inten- } \\
\text { sive and mixed development; } \\
\text { - New urban development and renovation of } \\
\text { neighborhood units to reduce energy }\end{array}$ & $\begin{array}{l}\text { consumption; } \\
\text { - Transfer of industrial centers and activities } \\
\text { outside the city borders; } \\
\text { - Increase the safety of cities against the risk of } \\
\text { natural disasters. }\end{array}$ \\
\hline & $\begin{array}{l}\text { Settlements } \\
\text { and built } \\
\text { environ- } \\
\text { ments }\end{array}$ & $\begin{array}{l}\text { - Measures to reduce energy and water de- } \\
\text { mand in the built environment; } \\
\text {-Creating green houses and buildings; } \\
\text { - Preservation of hills, land acquisition and } \\
\text { creation of wetlands against rising sea levels }\end{array}$ & $\begin{array}{l}\text { and floods; } \\
\text { - Development of standards and regulations for } \\
\text { climate change considerations in designs; } \\
\text { - Land use policies; Building codes and insur- } \\
\text { ance. }\end{array}$ \\
\hline & $\begin{array}{l}\text { Carbon se- } \\
\text { questration }\end{array}$ & $\begin{array}{l}\text {-Development of carbon dioxide absorption } \\
\text { programs from energy production in cities } \\
\text { in the long-term; } \\
\text {-Development of tree planting programs in }\end{array}$ & $\begin{array}{l}\text { cities; } \\
\text {-Development of natural carbon absorption } \\
\text { programs in cities. }\end{array}$ \\
\hline \multirow[t]{3}{*}{ Adaptation } & $\begin{array}{l}\text { Urban infra- } \\
\text { structures }\end{array}$ & $\begin{array}{l}\text { - Reducing carbon footprint from existing in- } \\
\text { frastructure networks; } \\
\text {-Use of renewable energy in urban infrastruc- } \\
\text { ture networks; } \\
\text {-Securing existing infrastructure networks; } \\
\text {-Paying attention to urban infrastructure }\end{array}$ & $\begin{array}{l}\text { against land subsidence; } \\
\text { - National policies in the field of water and inte- } \\
\text { grated management of water resources; } \\
\text { - Promotion of green infrastructure and water- } \\
\text { shed management (including urban forests). }\end{array}$ \\
\hline & $\begin{array}{l}\text { Urban } \\
\text { transport }\end{array}$ & $\begin{array}{l}\text {-Renovation of public transport fleet; } \\
\text {-Development of new mass transportation in- } \\
\text { frastructure such as metro and BRT; } \\
\text {-Replacing the transport fleet with more en- } \\
\text { ergy efficiency and less carbon emissions; } \\
\text {-Decrease in demand in personal transport } \\
\text { and increase in demand in public transport; } \\
\text {-Development of design and planning }\end{array}$ & $\begin{array}{l}\text { standards for roads, railways and other infra- } \\
\text { structure to deal with heating; } \\
\text {-Integration of climate change considerations } \\
\text { into transport policies at regional and local } \\
\text { levels; } \\
\text {-Development of general planning principles } \\
\text { for transportation networks in flood sensitive } \\
\text { areas. }\end{array}$ \\
\hline & Energy & $\begin{array}{l}\text {-Increasing energy efficiency through taxa- } \\
\text { tion, energy pricing, codes and standards, } \\
\text { campaigns of energy awareness and audit- } \\
\text { ing; } \\
\text {-Strengthening air transmission and distribu- } \\
\text { tion infrastructure; } \\
\text {-Development of renewable and low carbon }\end{array}$ & $\begin{array}{l}\text { energy and related technologies; } \\
\text {-Develop national energy policies, regulations } \\
\text { and financial incentives to encourage the use } \\
\text { of alternative sources; } \\
\text { - Using gases produced by landfills to provide } \\
\text { energy. }\end{array}$ \\
\hline
\end{tabular}

\section{Materials and Methods}

The present study is a type of evaluation research that aims to develop evaluation knowledge in the field of urban planning and the results can be used in future planning and decision making.

The term evaluation is widely used in planning to describe suggestions and their competence. It is more formally used to describe the process of analyzing a set of plans or projects by looking to discovery their relative advantages and disadvantages and setting 
the findings of these analyzes into a logical framework. The basis of evaluation is the assessment of the relative competence of different solutions [24]. Evaluation is a method and tool for recognizing the existing or potential effects and results of actions, activities and plans. In this regard, most studies use evaluation research to evaluate plans. Evaluation research is not a specific method for conducting research, but a research that is done with a specific purpose [25]. The case study is the urban development plans of Tehran. The present study tries to review and evaluate these plans from the view of climate change and data collection has been done by reviewing documents. Quantitative and qualitative content analysis is used for analyzing the information.

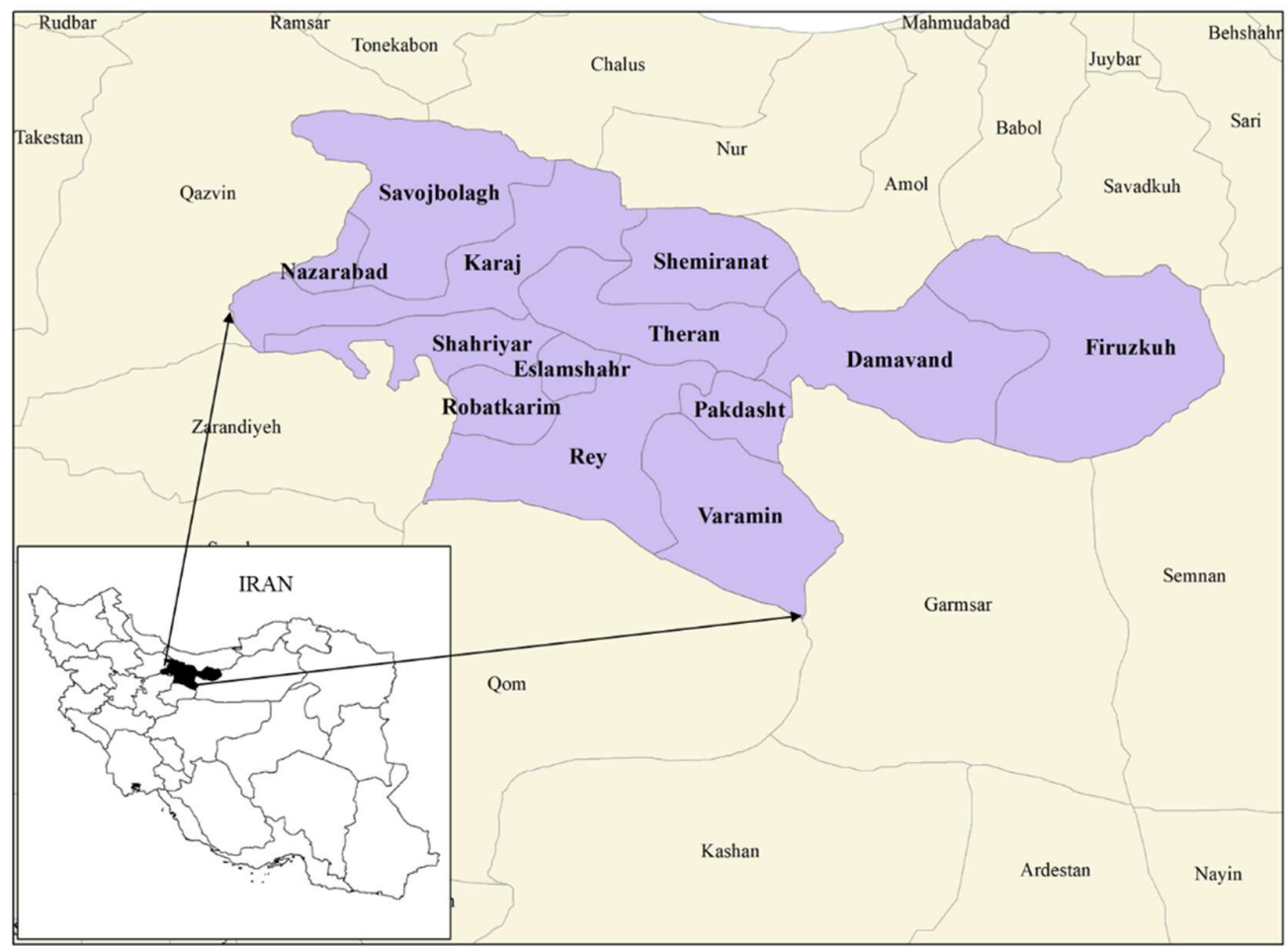

Figure 2. Map of Tehran Urban Area, Iran

\subsection{Evaluation and analysis methods}

The evaluation of a plan as it is in the document (plan) is called qualitative evaluation of that plan. In other words, in this method of evaluation, we do not seek the implementation of the plan or the conformity and performance of the plan with the external reality and external results, but the document and the text of the plan are examined.

Plan quality assessment research uses content analysis to "regularly read texts, images, and symbolic content". In plan quality research, the body of texts typically includes a set of plans with different domains [26]. According to Krippendorf (2013), the purpose of content analysis is that researchers be able to draw inferences from texts that are reproducible and valid [27].

Content analysis method was used to evaluate the plans. Content analysis is a research method that quantitatively analyzes a set of available data to find specific attributes in the data, such as duplicate patterns [25]. In general, according to what has been mentioned in most study sources, the steps that are mainly used in the content analysis of urban plans include the following:

1. Determining the subject of evaluation and identifying the characteristics;

2. Construction of a protocol consisting of criteria and indicators;

3. Determining the method and scoring of each item in the protocol;

4. Checking the accuracy and reliability of the information obtained from the coders;

5. Interpreting and analyzing the obtained information and measure the quality of the plan based on the specified features. 
After a thorough study of the plans and their alignment with the policies of mitigation and adaptation to the effects of climate change, they are coded and scored. In this study, 6 criteria and 31 indicators were used to evaluate eight urban development plans of Tehran. Firstly, the content of the plans were examined to rate the items. Then the adaptation and mitigation policies in terms of the amount of attention paid to them in the plans were scored based on very low (score 0), Low (scores 1 and 2), medium (score 3) and high (scores 4 and 5). Finally, with clarifying the scores of the dimensions and policies, the final score of the plans were determined.

\subsection{Sample Selection}

In this study, eight plans were selected from the ones that have been prepared for the city and region of Tehran in the last two decades (since the beginning of the 2000s). The sample selection was based on some criteria such as the comprehensiveness of the plans, the nature of the policy-making of the plans (except for the second and third five-year development plans of Tehran) and the diversity of the institutions that prepare or approve the plans (superior council of urban planning and architecture, Ministry of Roads and Urban Development, local government, Municipality and City Council). The plans studied for this purpose are presented in Table 4.

Table 4. Urban development Plans of Tehran

\begin{tabular}{llll}
\hline No. & Title of the Document & Consultant - Executive Institution & Year \\
\hline P1 & Tehran Urban Complex Plan & $\begin{array}{l}\text { Iran Urban Planning and Architecture Studies and Research Cen- } \\
\text { ter (Ministry of Housing and Urban Development) }\end{array}$ & 2002 \\
\hline P2 & $\begin{array}{l}\text { Vision Plan and Strategic Orientations } \\
\text { of Tehran on the horizon of 2025 }\end{array}$ & $\begin{array}{l}\text { Islamic Council of Tehran } \\
2006\end{array}$ \\
\hline P3 & $\begin{array}{l}\text { Tehran Master Plan } \\
\text { P4 }\end{array}$ & $\begin{array}{l}\text { Tehran Transport and Traffic Master } \\
\text { Plan }\end{array}$ & $\begin{array}{l}\text { Tran Urban Planning and Architecture Studies and Research Cen- } \\
\text { ter }\end{array}$ \\
\hline P5 & Tehran Province Spatial Plan Comprehensive Transport and Traffic Studies Company & 2007 \\
\hline P6 & $\begin{array}{l}\text { Second five-year development plan of } \\
\text { Tehran }\end{array}$ & Planning Deputy of Tehran provincial government & 2009 \\
\hline P7 & $\begin{array}{l}\text { Proposed plan to reduce air pollution in } \\
\text { Tehran }\end{array}$ & Transportation and Traffic Deputy of Tehran Municipality \\
\hline P8 & $\begin{array}{l}\text { Third five-year development plan of } \\
\text { Tehran }\end{array}$ & Islamic Council of Tehran & 2017 \\
\hline
\end{tabular}

\subsubsection{Tehran Urban Complex Plan}

This plan has objectives such as organizing future population housing, arranging urban and rural network of land, guiding and controlling land use, housing low-income groups (organizing informal sectors) and improving the urban management system and has been prepared in the scale of 1: 25000 to 1: 50,000. Plan of Tehran urban Complex and its surrounding cities is provided by the Iran Urban Planning and Architecture Studies and Research Center into 11 sections, including 9 sections of studies (including demographic, economic, social, natural, environmental, transportation, physical, multi-criteria evaluation and mathematic models of population distribution), a final report section (including past developments, future vision, goals and strategies for sustainable development of the complex, a strategic plan for the physical development of the complex, conditions for implementing the plan and rules and regulations of land use in the complex) and a section of relevant appendices.

\subsubsection{Vision Plan and Strategic Orientations of Tehran on the horizon of 2025}

Tehran Vision is a strategic document that outlines the desirable and possible image of Tehran in 2025 with a view to the 20-year vision of the country. The 20-year vision with 7 basic goals has named Tehran's long-term vision on the horizon of 2025 as "a cultural, knowledge-based, and standard cosmopolis in the Islamic world". This plan is very important because it shows the 20-year vision of Tehran. The strategic orientations of this 
plan are in 8 main axes including urban economy, urban infrastructure, urban management, urban security, transportation, environment, architecture and urban texture and cultural-social subjects.

\subsubsection{Tehran Master Plan}

The third master plan of Tehran (2007) includes traditional issues of master plans such as forecasting the population and households on the plan horizon (2025), determining the city area and boundaries, zoning of city lands, determining the per capita service network of the city, proposing the network of main roads and presenting construction rules and regulations in the city. In addition, new issues such as changing the structure and function of the city, reforming the revenue system of Tehran Municipality, improving urban infrastructures, improving the efficiency of the urban transportation system, ensuring the city safety against natural disasters and improving the quality of the urban environment have been discussed, which are not in the center of attention in former traditional master plans.

\subsubsection{Tehran Transport and Traffic Master Plan}

Today, problems and difficulties caused by transportation and traffic have involved large cities, as well as the metropolis of Tehran. In order to solve these problems, a master plan for transportation and traffic in Tehran was prepared and approved in 2007. The process of this plan is to simulate the current situation and predict future needs according to social and economic conditions, to provide appropriate solutions and options. So it is necessary to carry out a master plan for transportation and traffic in Tehran after preparing a master plan for the city of Tehran, because all studies, planning, design, solutions and decisions are presented in the form of this plan.

\subsubsection{Tehran Province Spatial Plan}

This plan includes 6 main study series with 55 expert sub-series including analysis of urban planning status, location and topography, water resources, architectural status, climate status, etc. Tehran province spatial plan is one of the most strategic regional plans that is prepared based on the country's superior documents. The law of the Fourth Development Plan obliges the government to implement the national document of land spatial planning at the macro, sectoral and provincial levels in order to properly distribute the population and activities in the territory, with the aim of efficient use of the capabilities and advantages of the country. The basic theory of provincial development at the provincial level contains the central and priority sections of provincial development and determines the role of the province in the division of national labor, the provincial spatial development organization and the basic measures.

\subsubsection{Second five-year development plan of Tehran}

This plan is the second five-year plan of Tehran, which includes the six missions of Tehran Municipality that has been considered transportation and traffic, environment and urban services, safety and crisis management, urban planning and architecture, social and cultural, intelligence and urban economy. Also, an estimate of resources and expenditures has been drawn to achieve the mentioned goals and missions.

\subsubsection{Proposed plan to reduce air pollution in Tehran}

This plan has been set based on the proposal of the Transportation and Traffic Deputy of Tehran Municipality to significantly reduce air pollution in Tehran during 4 years and has been prepared based on reducing the emission of pollutants from mobile sources. In this plan based on studies and calculations, has been predicted that the emission of particulate pollutants will be reduced by $55 \%$ and other gaseous pollutants by $45 \%$ within 4 years. It also includes projects such as the renovation and improvement of buses (including public and private transport), freight truck fleet, replacement of gasoline motorcycles with electric types, worn-out minibuses and renovation of the carburetor and worn passenger fleet. 


\subsubsection{Third five-year development plan of Tehran}

This plan has been prepared for the period of 2019-2023 by focusing on national documents including the constitution, general policies announced by the Supreme Leader, the sixth development plan, master and detailed plans of Tehran and the policies of the Islamic Council of Tehran. It is logically both the development plan and the structural reform plan of Tehran Municipality. This plan has three levels of integration including: spatial integration, thematic integration and stakeholder integration. "Viability", "transparency", "reducing inequality", "developing justice" and "improving good urban governance" are important goals of this plan.

\section{Discussion}

\subsection{The effects of climate change on the metropolitan area of Tehran}

Climate change has global and national effects on all countries, as well as country of Iran. Although a country like Iran is more vulnerable to climate change due to environmental degradation. These changes can be assessed at the macro level of the country and regions. Climate change show their effects through long and hot summers, short and hot winters, heavy and destructive rains, floods on the coast, outbreaks of pests and plant and animal diseases, early and long seasonal fires, water scarcity and drought, desertification, land subsidence and the creation of massive sinkholes in the heart of cities and increase in dust and air pollution. Heavy rains, air pollution and increasing dust in different cities, land subsidence as a major problem in Tehran, Are just a part of natural events that can be attributed to climate change. The fact is that the variety and intensity of these events has been increased specially during the last years.

Climate change is now a global issue, as unusual and distinct changes in expected patterns. Its effects is more tangible for citizens because of the special importance of cities as major population centers. The metropolis of Tehran is not an exception in this way. Especially considering the high share of Tehran as the main center of population attraction, the high share in GDP and the numerous roles in the cultural and political domains, phenomena such as severe storms, dust, land subsidence and water scarcity which are affected by climate change, can severely affect development plans. In the following, the most important effects of climate change in the metropolitan area of Tehran are examined with emphasis on issues related to urban planning and infrastructure.

\subsubsection{Land subsidence}

There are 43 types of natural hazards that have been identified in the world so far, which most of them are atmospheric hazards. More than 30 natural hazards have been identified in Iran which one of them is land subsidence. This risk has been added to the country's hazards in the last 15 years and may cause the greatest amount of financial damages [28]. Land subsidence is one of the most important geological hazards that have received less attention due to low human casualties compared to other sudden natural phenomena such as earthquakes, landslides and floods. This phenomenon is usually associated with many risks. One of these risks is changing in the topography of the earth's surface, which in most cases is irreversible. Subsidence is a global issue and has been seen in the most plains of Iran (figure 3).

This phenomenon can damage streets, bridges and highways and threat important structures such as refineries, power plants, airports and gas facilities, disrupt the efficiency of water supply, oil, gasoline, and sewage networks and create damages to buildings. Linear structures such as railways, pipelines and irrigation canals are more vulnerable in these conditions [29]. The phenomenon of subsidence is spreading rapidly due to over-harvesting of groundwater, increasing development of water consumption in urban areas and the high consumption of water in agricultural lands.

The intensity of subsidence in some plains of Iran, including Tehran plain, is at least 90 times higher than the most critical conditions in developed countries. The rate of subsidence in the world is $4 \mathrm{~mm}$ per year and this rate is considered critical in many countries. However, the rate of subsidence in the Tehran plain in 2006 was about $17 \mathrm{~cm}$ but it has 
increased to $36 \mathrm{~cm}$ in recent years [30]. The plain on which most of Tehran is spread; In other words, every day about one millimeter of Tehran subsides. According to the studies, districts of 16, 17, 18, 19 and 20 of Tehran Municipality and the cities like Islamshahr, Shahriyar, Chahardangeh, Nasimshahr, Sabashahr and Kahrizak are affected by the subsidence of the Tehran plain [31]. About $25 \mathrm{~km}$ of Azadegan belt, $28 \mathrm{~km}$ of Qom highway and $21 \mathrm{~km}$ of Saveh road and Behesht Zahra highway as the main movement axes of goods and passengers in Tehran province, are in the danger of land subsidence [31].

There are not only the roads leading to the Capital are under the threat of land subsidence, but also the subsoil of the railway, gas station and runway of Mehrabad Airport. Improper usage of water from aquifers is the most important cause of this catastrophe. In addition, the worn-out city water pipes and the leakage from them is another factor in this great threat.

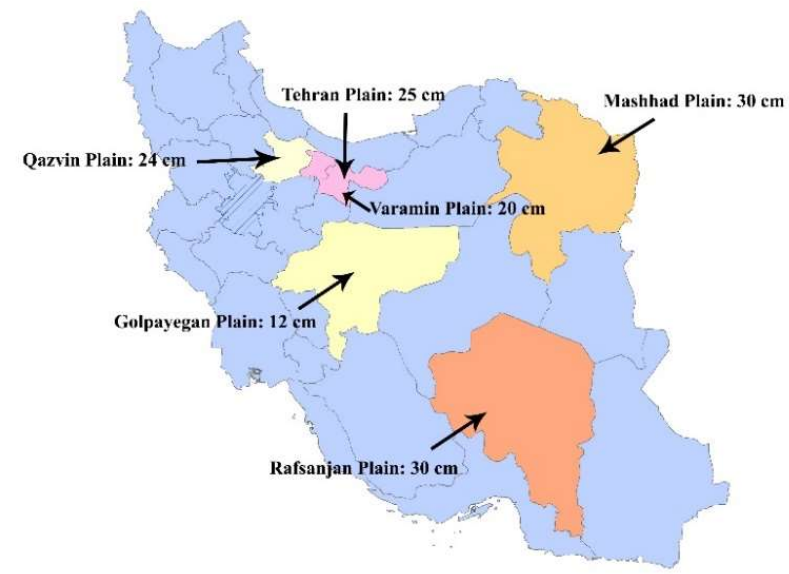

Figure 3: Maximum land subsidence rate in a number of plains of the country until 2016 [32]

\subsubsection{Production and emission of air pollutants}

The problem of air pollution does not allocate to a specific region of the world and all countries face its consequences. Many countries have taken effective measures against the spread of air pollution with a unit management and have been able to improve the situation to exit from the group of polluted and bio-hazardous areas. Due to global climate change and environmental crises, air pollution in Iran is also an important environmental problem and in recent years, in large cities like Tehran, it has intensified due to special geographical, climatic and strategic conditions [33].

Air pollution is one of the main problems of this metropolis. Tehran is the largest industrial and commercial hub in the country. Natural factors, urban construction form, existence of more than three million active cars and 700,000 motorcycles, 17,000 industrial and guild units (equivalent to 25 percent of the total industries in the country), consumption of about 20 percent of the total energy, concentration of 70 percent of services and 80 percent of specialists, has converted Tehran to one of the most polluted cities in the world [34].

Studies show that 90 percent of air pollutants in Tehran are from vehicles and 10 percent of fixed sources. More than three-quarters of the weight of air pollutants is carbon monoxide and about 8 percent of that is generated by vehicles. About half of this amount is emitted by city light vehicles and $20 \%$ by motorcycles. According to the World Bank, air pollution damage in Iran is estimated at \$ 1.7 billion in 2001 to $\$ 8$ billion in 2006 and $\$ 16$ billion in 2016 [34].

Tehran is ranked 12th among 26 major cities in the world in terms of PM10 pollutant (Figure 4). In 2016, the average annual concentration of PM10 in Tehran was about 77 micrograms per cubic meter (approximately 4 times of the threshold allowed by the World Health Organization) [35]. 


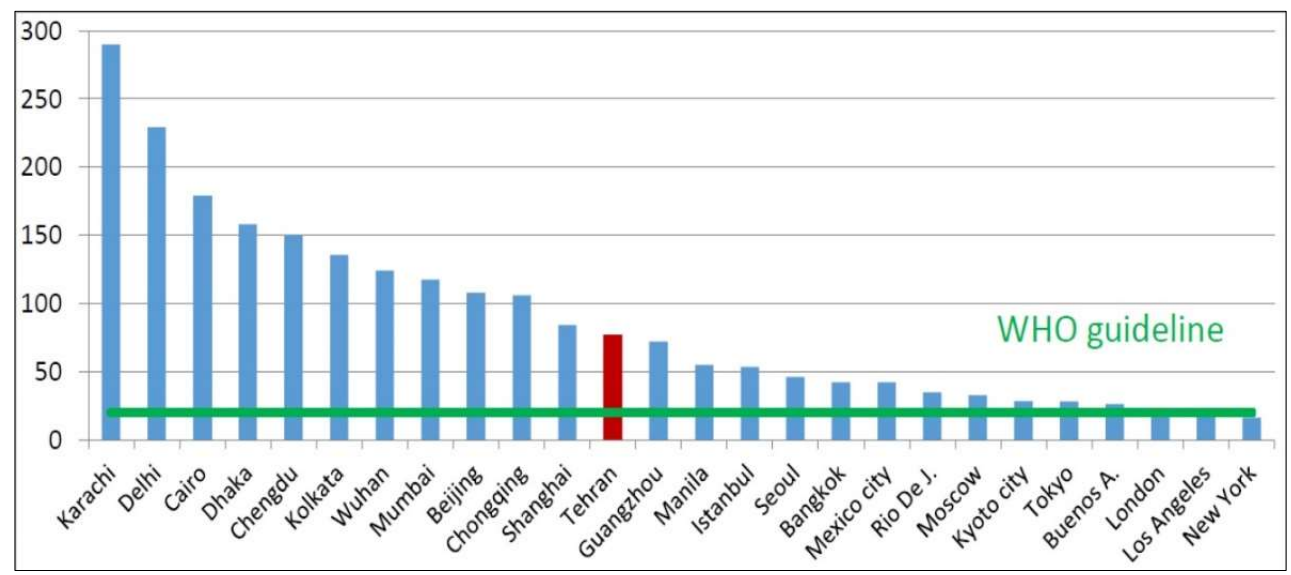

Figure 4: Annual PM10 concentration in major cities of the world (megacity) [35]

\subsection{Evaluate selected plans}

Reviewing the plans related to the effects of climate change is important because they play an important and effective role in mitigating or adapting to these changes at different national, regional and local scales and levels. The place of climate change in the country's planning documents is a subject that has been less paid attention and therefore in the present study, the recognition of policies are taken into account which mitigate the effects of climate change in the plans prepared for Tehran.

In this research, eight city and region development plans of Tehran have been evaluated using content analysis method. One of the most important steps in quantitative content analysis is to score each item in the protocol. This step is dedicated to determining the method and scoring each item in the protocol. In this study, the type of scoring is based on very low (score 0 ), low (score 1 and 2 ), medium (score 3 ) and high (score 4 and 5 ). After reviewing the plan by the coder, there is a corresponding score in the protocol for each item. First, these plans are evaluated qualitatively and the strategies and policies which are considered in the plans to deal with the effects of climate change are identified and analyzed. Then, using the method, their quantitative evaluation has been done. The results of plan evaluation are shown in Table 5. 
Table 5. Evaluation of mitigation and adaptation policies to the effects of climate change on urban development plans of Tehran

\begin{tabular}{|c|c|c|c|c|c|c|c|c|c|c|c|c|}
\hline \multirow{2}{*}{ Dimensions } & \multirow{2}{*}{ Policies } & \multicolumn{8}{|c|}{ PLANS } & \multirow{2}{*}{ Ave. } & \multirow{2}{*}{ Score(\%) } & \multirow{2}{*}{$\begin{array}{c}\text { Ave. } \\
\text { score }(\%)\end{array}$} \\
\hline & & P1 & P2 & P3 & P4 & P5 & P6 & P7 & P8 & & & \\
\hline \multirow[t]{5}{*}{$\begin{array}{l}\text { Urban De- } \\
\text { velopment }\end{array}$} & $\begin{array}{l}\text { Land use planning and urban design } \\
\text { to limit energy consumption }\end{array}$ & High & Very Low & High & Very Low & High & High & Very Low & Medium & Medium & $57.5 \%$ & \multirow{5}{*}{$45.5 \%$} \\
\hline & $\begin{array}{l}\text { Reuse abandoned lands to encourage } \\
\text { intensive and mixed development }\end{array}$ & Very Low & Very Low & Low & Very Low & Very Low & Very Low & Very Low & Very Low & Low & $2.5 \%$ & \\
\hline & $\begin{array}{l}\text { New urban development and renova- } \\
\text { tion of neighborhood units to reduce } \\
\text { energy consumption }\end{array}$ & Very Low & Very Low & High & Very Low & Very Low & High & Very Low & High & Medium & $37.5 \%$ & \\
\hline & $\begin{array}{l}\text { Transfer of industrial centers and ac- } \\
\text { tivities outside the city borders }\end{array}$ & High & Medium & High & Very Low & Very Low & High & Low & High & Medium & $60 \%$ & \\
\hline & $\begin{array}{l}\text { Increase the safety of cities against the } \\
\text { risk of natural disasters }\end{array}$ & High & High & High & Very Low & Medium & High & Very Low & High & High & $70 \%$ & \\
\hline \multirow{5}{*}{$\begin{array}{l}\text { Settlements } \\
\text { and built } \\
\text { environ- } \\
\text { ments }\end{array}$} & $\begin{array}{l}\text { Measures to reduce energy and water } \\
\text { demand in the built environment }\end{array}$ & Very Low & Medium & Low & Very Low & Low & High & Very Low & Low & Low & $27.5 \%$ & \multirow{5}{*}{$28 \%$} \\
\hline & Creating green houses and buildings & Very Low & Very Low & Very Low & Very Low & Very Low & Very Low & VeryLow & Very Low & Very Low & $0 \%$ & \\
\hline & $\begin{array}{l}\text { Preservation of hills, land acquisition } \\
\text { and creation of wetlands against rising } \\
\text { sea levels and floods }\end{array}$ & High & Very Low & High & Very Low & Medium & High & Very Low & Medium & Medium & $52.5 \%$ & \\
\hline & $\begin{array}{l}\text { Development of standards and regula- } \\
\text { tions for climate change considera- } \\
\text { tions in designs }\end{array}$ & Very Low & Medium & Medium & Very Low & Very Low & Low & Low & Low & Low & $22.5 \%$ & \\
\hline & $\begin{array}{l}\text { Land use policies; Building codes and } \\
\text { insurance }\end{array}$ & Medium & Very Low & Medium & Very Low & Medium & Medium & Very Low & Medium & Medium & $37.5 \%$ & \\
\hline \multirow[t]{3}{*}{$\begin{array}{l}\text { Carbon se- } \\
\text { questration }\end{array}$} & $\begin{array}{l}\text { Development of carbon dioxide ab- } \\
\text { sorption programs from energy pro- } \\
\text { duction in cities in the long-term }\end{array}$ & Very Low & Medium & Medium & Very Low & Low & Low & Low & Low & Low & $25 \%$ & \multirow{3}{*}{$47.5 \%$} \\
\hline & $\begin{array}{l}\text { Development of tree planting pro- } \\
\text { grams in cities }\end{array}$ & High & Very Low & Medium & High & High & High & Very Low & High & High & $70 \%$ & \\
\hline & $\begin{array}{l}\text { Development of natural carbon ab- } \\
\text { sorption programs in cities }\end{array}$ & Medium & Medium & Medium & Low & Low & Medium & Very Low & High & Medium & $47.5 \%$ & \\
\hline \multirow[t]{5}{*}{$\begin{array}{l}\text { Urban infra- } \\
\text { structures }\end{array}$} & $\begin{array}{l}\text { Reducing carbon footprint from exist- } \\
\text { ing infrastructure networks }\end{array}$ & Medium & Medium & Medium & Medium & Low & High & High & High & High & $70 \%$ & \multirow{5}{*}{$48.7 \%$} \\
\hline & $\begin{array}{l}\text { Use of renewable energy in urban in- } \\
\text { frastructure networks }\end{array}$ & Very Low & ery Low & Very Low & yow & Very Low & Very Low & yLow & Low & Low & $2.5 \%$ & \\
\hline & $\begin{array}{l}\text { Securing existing infrastructure net- } \\
\text { works }\end{array}$ & High & High & High & Low & Very Low & High & Very Low & High & High & $65 \%$ & \\
\hline & $\begin{array}{l}\text { Paying attention to urban infrastruc- } \\
\text { ture against land subsidence }\end{array}$ & Very Low & Very Low & Low & Very Low & Medium & Medium & Very Low & High & Low & $30 \%$ & \\
\hline & $\begin{array}{l}\text { National policies in the field of water } \\
\text { and integrated management of water } \\
\text { resources }\end{array}$ & Very Low & Medium & High & Very Low & High & High & Very Low & High & Medium & $57.5 \%$ & \\
\hline
\end{tabular}




\begin{tabular}{|c|c|c|c|c|c|c|c|c|c|c|c|c|}
\hline & $\begin{array}{l}\text { Promotion of green infrastructure and } \\
\text { watershed management (including ur- } \\
\text { ban forests) }\end{array}$ & High & Low & High & Low & High & High & Very Low & High & High & $67.5 \%$ & \\
\hline \multirow{7}{*}{$\begin{array}{l}\text { Urban } \\
\text { transport }\end{array}$} & Renovation of public transport fleet & Very Low & High & Low & High & Low & High & High & High & High & $67.5 \%$ & \multirow{7}{*}{$54.3 \%$} \\
\hline & $\begin{array}{l}\text { Development of new mass transporta- } \\
\text { tion infrastructure such as metro and } \\
\text { BRT }\end{array}$ & Medium & Low & Low & High & High & High & High & High & High & $67.5 \%$ & \\
\hline & $\begin{array}{l}\text { Replacing the transport fleet with } \\
\text { more energy efficiency and less carbon } \\
\text { emissions }\end{array}$ & Medium & Medium & Medium & High & Low & High & High & High & High & $75 \%$ & \\
\hline & $\begin{array}{l}\text { Decrease in demand in personal } \\
\text { transport and increase in demand in } \\
\text { public transport }\end{array}$ & Medium & High & High & High & High & High & High & High & High & $95 \%$ & \\
\hline & $\begin{array}{l}\text { Development of design and planning } \\
\text { standards for roads, railways and } \\
\text { other infrastructure to deal with heat- } \\
\text { ing }\end{array}$ & Very Low & Low & Medium & Low & Very Low & Very Low & Low & Low & Low & $17.5 \%$ & \\
\hline & $\begin{array}{l}\text { Integration of climate change consid- } \\
\text { erations into transport policies at re- } \\
\text { gional and local levels }\end{array}$ & Very Low & Medium & Medium & Medium & Low & Medium & Medium & High & Medium & $52.5 \%$ & \\
\hline & $\begin{array}{l}\text { Development of general planning } \\
\text { principles for transportation networks } \\
\text { in flood sensitive areas }\end{array}$ & Very Low & Low & Very Low & Low & Very Low & Very Low & Very Low & Very Low & Low & $5 \%$ & \\
\hline \multirow{3}{*}{ energy } & $\begin{array}{l}\text { Development of renewable and low } \\
\text { carbon energy and related technolo- } \\
\text { gies }\end{array}$ & Very Low & Medium & Medium & Very Low & Very Low & Medium & Very Low & High & Medium & $35 \%$ & \multirow[t]{3}{*}{$20.5 \%$} \\
\hline & $\begin{array}{l}\text { Develop national energy policies, reg- } \\
\text { ulations and financial incentives to en- } \\
\text { courage the use of alternative sources }\end{array}$ & Very Low & Medium & Medium & Very Low & Very Low & Medium & Very Low & Low & Low & $25 \%$ & \\
\hline & $\begin{array}{l}\text { Using gases produced by landfills to } \\
\text { provide energy }\end{array}$ & Very Low & High & High & Very Low & Very Low & Very Low & Very Low & Very Low & Low & $25 \%$ & \\
\hline \multicolumn{2}{|c|}{$\begin{array}{c}\text { Reflection of the effects of climate change in the } \\
\text { plans (percentage) }\end{array}$} & $34.2 \%$ & $41.9 \%$ & $58.7 \%$ & $23.2 \%$ & $31.6 \%$ & $61.9 \%$ & $20.6 \%$ & $61.3 \%$ & \multirow[t]{2}{*}{ Medium } & \multirow{2}{*}{\multicolumn{2}{|c|}{$41.45 \%$}} \\
\hline & Rank & 5 & 4 & 3 & 7 & 6 & 1 & 8 & 2 & & & \\
\hline
\end{tabular}


According to the analysis, the highest attention to policies of mitigation and adaptation in the plans is related to the transportation sector with $55 \%$ and the lowest is related to the energy sector with 23 percent. The second and third five-year development plans of Tehran with $61.9 \%$ and $61.3 \%$, have the highest rate of reflection of the climate change effects and strategies to deal with them, and the plan to reduce air pollution in Tehran with $21 \%$ has the lowest. Based on the reviews, it can be concluded that considering that climate change has had very detrimental effects on Tehran and will continue to do so in the future. Therefore it is necessary to consider to the mitigation and adaptation policies in the future plans.

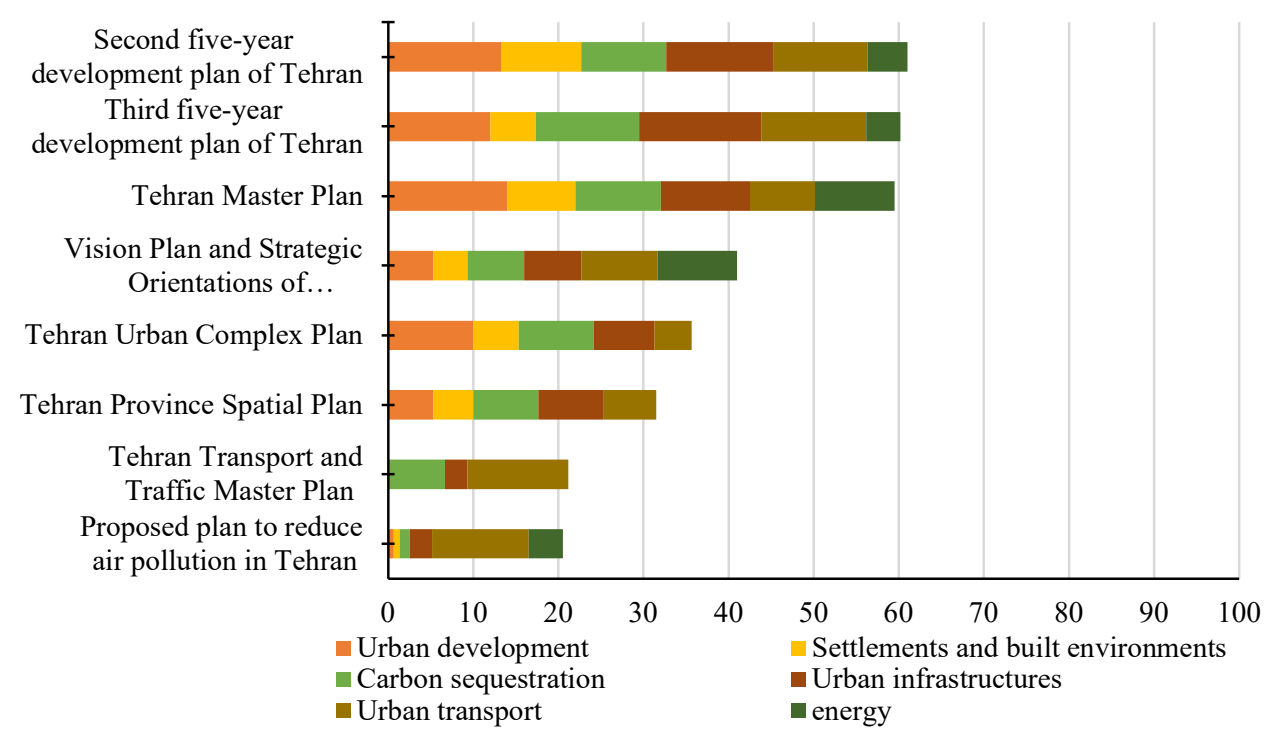

Figure 5. The extent of reflection of the climate change effects in Tehran development plans

This study showed that the development plans of Tehran have made relative progress in terms of reflecting the effects of climate change and strategies to deal with them during the last two decades. Findings indicate that among these plans, the second and third five-year development plans of Tehran have the highest rate and the plan to reduce air pollution in Tehran has the lowest rate of attention to the effects of climate change. In general, some recommendations can be made to improve the quality of plans in terms of reflecting the effects of climate change, including:

- Assigning a separate topic related to climate change and strategies to deal with its destructive effects in the scope of urban development plans;

- $\quad$ Reviewing the plan to reduce air pollution of Tehran and entitled other cases of pollution

- Improving the quality and content of plans related to crisis management in Tehran

- Preparation of disaster risk and vulnerability reduction plan for the city of Tehran

- Special attention to the development of methane gas control and collection system in landfills in urban development plans

- $\quad$ Serious emphasis on energy (renewable energy) and carbon sequestration, especially in the scope of urban development plans

- $\quad$ Preparation of documents and thematic-local plans for the phenomenon of land subsidence in the metropolis of Tehran

- $\quad$ Development of urban greenery and tree planting plans in Tehran

\section{Conclusions}

According to the global statistics, among the 41 natural disasters, 31 of them occur in Iran which drought has caused the most damage due to climate change and floods. Due to the decrease in rainfall and the digging of illegal wells, the number of forbidden plains 
in the country has increased significantly in recent years and the phenomenon of subsidence can be seen in most parts of Tehran. The climate change will definitely have negative impacts on the world economy and will cause problems for all countries. At the urban and local scale, urban development plans will play an important role in reflecting its effects and ways to deal with them. Therefore in this study, the development plans of Tehran have been evaluated in terms of reflecting the harmful effects of climate change on the metropolitan area of Tehran.

Climate change is one of the most challenging global issues affecting human and natural systems around the world. The need for immediate action to reduce greenhouse gas emissions is quite evident. Otherwise, it will lead to devastating and possibly irreversible changes in the environment and this will have a profound impact on human society. Due to the current and predicted emission scenarios, the effects of climate change can no longer be avoided. Therefore, adapting to these changes is crucial. Local governments must make their effort to change the situation. They can play a key role in reducing greenhouse gas emissions by controlling land use, transportation, energy systems and green buildings, waste management and food production. Severe weather events, infrastructure degradation, land subsidence, water scarcity, food insecurity, rising sea levels and community health issues are just some of the challenges that climate change may pose. Local governments can control these destructive effects through urban development plans and take the necessary measures to mitigate and adapt to them. Therefore, urban development plans play a very important role in this regard.

In this research, we evaluated eight development plans of Tehran using the content analysis method. The conceptual framework of this research includes 6 dimensions and 31 indicators. According to the research findings, the highest level of attention to the climate change effects and related strategies have been done in the second and third fiveyear development plans of Tehran by about 62 percent. Tehran Master Plan with 59\%, Urban Complex Plan with 34\%, Tehran province spatial plan with $32 \%$, Transportation Master Plan with 23\% and the Plan to reduce air pollution with $21 \%$, were respectively the most to the least extent of reflecting the effects of climate change in their policies. According to reviews, the highest attention between the climate change mitigation / adaptation policies is paid to the urban transport with about $55 \%$ and the least attention to energy dimensions with $23 \%$ and settlements and environments built with $28 \%$. Generally, some dimensions have been paid very little attention in terms of reflecting climate change effects and proposed policies and solutions and it is necessary to pay more attention to the reflection of these effects in future plans.

Funding: This research received no external funding.

Conflicts of Interest: The authors declare no conflict of interest.

\section{References}

1. Zhao, Ch.; Yan, Y.; Wang, Ch. Adaptation and mitigation for combating climate change - from single to joint. Eco. Health and Sustainability. 2018, 4, 85-90, doi: org/10.1080/20964129.2018.1466632.

2. Friesecke, F.; Schetke, S.; Kötter, T. Urban Planning for Climate Change. Position Paper of FIG Working Group 8.1. Planning, Environment and Water Management. 2012, 3-12.

3. Wheeler, S. Urban Planning and Global Climate Change, 5th ed.; Publisher: city reader, 2010; pp. 458-467.

4. Un-Habitat. World cities report, Urbanization and Development. Publisher: United Nations Human Settlements Programme, 2016, 1-262.

5. Broto, V.; Bulkeley, H. A survey of urban climate change experiments in 100 cities. Global Environmental Change. 2013, 23, 92-102, https://doi.org/10.1016/j.gloenvcha.2012.07.005.

6. Measham, T.; Pretson, B.; Smith, T.; Brooke, C.; Gorddard, R.; Withycombe, G.; Morrison, C. Adapting to climate change through local municipal planning: barriers and challenges. Mitigation and Adaptation Strategies for Global Change. 2011, 16, 889-909, doi: 10.1007/s11027-011-9301-2.

7. Un-Habitat. UN-HABITAT pitches for urban planning, Bonn. 2007.

8. Yuen, B.; Kong, L. Climate Change and Urban Planning in Southeast Asia. Surveys and Perspectives Integrating Environment and Society, 2009, 2, 1-12. DOI:10.1142/9789814280730_0001. 
9. Reckien, D.; Salvia, M.; Heidrich, O.; Church, J. How are cities planning to respond to climate change? Assessment of local climate plans from 885 cities in the EU-28. Journal of Cleaner Production. 2018, 191, 207-219, DOI:10.1016/j.jclepro.2018.03.220.

10. Stevens, R.; Senbel, M. Are municipal land use plans keeping pace with global climate change?. Land Use Policy. 2017, 68, 1-14, https://doi.org/10.1016/j.landusepol.2017.07.026.

11. Hu, Q. Evaluating Climate Change Mitigation and Adaptation Policies on the U.S. 50 States Hazard Mitigation Plans. Community and Regional Planning Program: Student Projects and Theses. For the degree of Master of Community and Regional Planning, University of Nebraska. 2017, 43 p.

12. Viegas, C.; Saldanha, D.; Bond, A.; Ribeiro, J.; Selig, P. Urban land planning: The role of a Master Plan in influencing local temperatures. Cities, 2013, 35, 1-13, https://doi.org/10.1016/j.cities.2013.05.006.

13. Pitt, D. The impact of internal and external characteristics on the adoption of climate mitigation policies by US municipalities. Environment and Planning C: Government and Policy. 2009, 28, 851 - 871, https://doi.org/10.1068/c09175.

14. Sterman, J. Business Dynamics, System Thinking and Modeling for a Complex World. Publisher: McGraw-Hill. 2000, 982p.

15. Pahlevan, K. Climate change, the biggest challenge of current century. Consulting Engineer Quarterly. 2017, 76, 53-57.

16. Rahimi, J.; Bazrafshan, J. Investigation of changes in rainy days under the influence of micro-urban climate in Tehran metropolis. Quarterly Journal of Natural Geography Research. 2011, 77.

17. World Economic Forum, 2019. Available online: https://www.weforum.org/agenda/2019/06/chart-of-theday-these-countries create-most-of-the-world-s-co2-emissions. 2020.

18. Un-Habitat. Cities and climate change, Global report on human settlements. Publisher: Earthscan. 2011.

19. Heidrich, O.; Reckien, D.; Olazabal, M.; Foley, A. National climate policies across Europe and their impacts on cities strategies. Journal of Environmental Management. 2016, 168, 36-45, https://doi.org/10.1016/j.jenvman.2015.11.043.

20. Ford, A.; Dawson, R.; Blythe, Ph.; Barr, S. Land-use transport models for climate change mitigation and adaptation planning. Journal of transport and land use. 2018, 11, 83-101, https://doi.org/10.5198/jtlu.2018.1209.

21. Wilbanks, T. J., Romero Lankao, P., Bao, M., Berkhout, F., Cairncross, S., Ceron, J.-P. Industry, settlement and society. In Climate change 2007: Impacts, adaptation and vulnerability. Contribution of working group II to the fourth assessment report of the Intergovernmental Panel on Climate Change. Publisher: Cambridge University Press. 2007, 357-390.

22. Carter, J.; Cavan, G.; Connelly, A. Climate change and the city: Building capacity for urban adaptation. Progress in Planning. 2015, 95, 1-66, https://doi.org/10.1016/j.progress.2013.08.001.

23. Un-Habitat. Planning for Climate Change: A strategic, values-based approach for urban planners. 2014.

24. Lichfield, N.; Kettle, P.; Whitbread, M. Evaluation in the Planning Process. Urban and Regional Planning Series. 1975, 10, pp. 1-344, https://doi.org/10.1016/C2013-0-02598-4.

25. Baker, T. Doing social research. Publisher: McGraw-Hill. 1994, 499p.

26. Stevens, M.; Berke, P.; Lyles, W. Measuring and Reporting Intercoder Reliability in Plan Quality Evaluation Research. Journal of Planning Education and Research. 2014, 34, 77-93, https://doi.org/10.1177/0739456X13513614.

27. Krippendorff, K. Content Analysis: An Introduction to Its Methodology, 3rd ed.; Publisher: Sage, 2013; pp. 1-441.

28. Geological Survey \& Mineral Exploration of IRAN. Earthquakes are unpredictable anywhere in the world. Monthly Journal of Earth and Mining Sciences. 2017, 141, 48p.

29. Ganji, N. Dead Earth, what happens to the areas exposed to landslides?. Business Weekly. 2016, 209, 82-85.

30. Water Research Institute of the Ministry of Energy. Monitoring the rate and range of subsidence of the country plains to an up to date and online form using satellite images (Case study: Tehran and Alborz province plains). 2018.

31. Zafari, H.; Rohani, M. Reviewing the Consequences of Groundwater Loss Crisis (Case Study of Tehran). Crisis Management. 2017, 31, 97-124.

32. Geological Survey \& Mineral Exploration of Iran, 2016.

33. Bidhendi, N.; Mohammadnezhad, Gh.; Ebadati, Sh. Concepts and consequences of climate change with an overview of the Kyoto Protocol. Tehran: University of Tehran. 2008.

34. Ghyebashi, A.; Poorezat, A.; Hafeznya, M.; Mohammadi, H.; Zolfagharzade, M. Foresight of the interaction of climate change and air pollution in the metropolis of Tehran. Fourth International Conference on Planning and Management. 2017, 12p.

35. Naderi, M.; Abbassian, M. World Bank report on air pollution in Tehran. Report of the World Bank and Air Quality Control Company. 2017. 